\title{
Activation of Mouse Metallothionein-I Promoter in Mouse Preimplantation Embryos After Pronuclear Microinjection
}

\author{
Satoshi TAKEDA ${ }^{1,2)}$, Sadahiro AZUMA ${ }^{1)}$, Tohru TSUKUI') and \\ Yutaka TOYODA ${ }^{1,3)}$
}

1) Department of Reproductive and Developmental Biology, Institute of Medical Science, The University of Tokyo, 4-6-1 Shirokanedai, Minato-ku, Tokyo 108, ${ }^{2)}$ Otsuka GEN Research Institute, Otsuka Pharmaceutical Co.Ltd., 463-10 Kawauchi-cho, Kagasuno, Tokushima 771-01, and

3) The Research Center for Protozoan Molecular Immunology, Obihiro University of Agriculture and Veterinary Medicine, 11 Nishisen, Inada-cho, Obihiro 080, Japan

\begin{abstract}
To analyze expression of developmental genes and their regulatory mechanisms in mouse preimplantation embryos, pronuclei of in vitro-fertilized eggs were microinjected 8-10 h after insemination (hpi) with a fusion gene composed of the mouse metallothionein-I promoter (MT-I) and the Escherichia coli $\beta$-galactosidase gene (lacZ). The eggs were cultured up to the blastocyst stage in Whitten's medium supplemented with $100 \mu \mathrm{M}$ EDTA. Expression of the lacZ gene was examined by staining the embryos with X-gal as a substrate. Expression was first detected at the 2-cell stage, $27 \mathrm{hpi}$; the proportion of embryos expressing the lac $Z$ gene reached a maximum of $80 \%$ at 33-48 hpi. The proportion declined from the 4-cell stage onward, but some embryos still showed positive staining at the blastocyst stage. $\alpha$-Amanitin blocked the expression of lac $Z$ gene only when added before $12 \mathrm{hpi}$, suggesting that transcription had started during the pronuclear stage rather than in cleavage stages. The presence of EDTA in the culture medium reduced the expression markedly from the morula stage on, but $25 \mu \mathrm{M} \mathrm{ZnCl}_{2}$ enhanced expression after the 4-cell stage in the presence of EDTA. These results suggest that transcription is active at the pronuclear stage and that the MT-I promoter becomes inducible by $\mathrm{ZnCl}_{2}$ after activation of the embryonic genome.

Key words: Mouse preimplantaion embryo, Embryonic genome activation, Metallothionein-I promoter, X-gal staining.
\end{abstract}

(J. Reprod. Dev. 43: 321-328, 1997)

$\mathbf{T}$ ranscription of genes is active during oogenesis in the mouse [1]; then poly(A)+ RNA decreases at the oocyte maturation from germinal vesicle breakdown until ovulation [2]. After that, poly(A)+ RNA [3], $\alpha$-actin mRNA [4] and histone mRNA [5] increase during the course of early embryonic development. It has been deduced that activation of the embryonic mouse genome first occurs at the 2-

Accepted for publication: July 30, 1997

Correspondence: S. Takeda cell stage [6]; which appears to be independent of DNA synthesis [7], cell cycle [8] and nuclear/cytoplasm ratio [9]. Recent studies suggest that activation of genes in the zygote may occur at the G2 phase of the 1-cell stage [10]. However, the mechanism has not been clarified.

Microinjection of an easily detectable marker gene into the pronuclear egg is an especially useful technique for investigating transcriptional activity in preimplantation embryos. In a previous report [11] we showed that the SV40-lacZ gene 
injected into the pronuclei was expressed from the 4-cell to the blastocyst stages in preimplantation embryos cultured in vitro.

In the work reported here we examined lacZ expression driven by the promoter of an inducible gene, mouse metallothionein-I (MT-I), in order to analyze an epigenetic effect on gene expression during preimplantation development. Our results suggest that this construct (ML) was transcribed during the pronuclear stage; $\beta$-galactosidase activity became detectable at the late 2-cell stage, and this activity was enhanced by the addition of $\mathrm{ZnCl}_{2}$ to the culture medium after embryonic genome activation.

\section{Materials and Methods}

In vitro fertilization and culture of embryos

In vitro fertilization was performed as described by Toyoda et al. [12]. Briefly, female F1 (C57BL/ $6 \mathrm{~N} \times$ DBA2) mice, $2-5$ months old, were superovulated by intraperitoneal injections of equine chorionic gonadotropin and human chorionic gonadotropin, given $48 \mathrm{~h}$ apart. Spermatozoa obtained from the cauda epididymis of mature (3-5 month-old) male F1 (C57BL / 6N × DBA2) mice were preincubated for $1 \mathrm{~h}$ in fertilization medium (TYH). The time course was described as hours post insemination (hpi), 0 hpi being the time when the preincubated sperm were introduced into the fertilization medium containing eggs. Fertilized eggs were cultured in Whitten's medium [13]. Ethylenediamine-tetraacetic acid (EDTA, disodium salt) $[14,15]$, zinc chloride $\left(\mathrm{ZnCl}_{2}\right)$ and $\alpha$-amanitin were added to the culture medium according to the experimental design; to clalify when the exogenous ML gene began to be transcribed, $\alpha$-amanitin (10 $\mu \mathrm{g} / \mathrm{ml}$ ) was added to the Whitten's medium supplemented with $100 \mu \mathrm{M}$ EDTA at different times between 12 and $24 \mathrm{hpi}$, and $\beta$-galactosidase activity was examined at $36 \mathrm{hpi}$. To clarify the effects of supplementation with $\mathrm{ZnCl}_{2}$ on expression of $\mathrm{ML}$, the embryos were transferred to the culture media supplemented with $25 \mu \mathrm{M} \mathrm{ZnCl}_{2}$ at 12, 24, 48 and $72 \mathrm{hpi}$, then $\mathrm{x}$-gal staining was carried out at 24 , 48,72 and 96 hpi, respectively.

\section{Construction of $p M L$}

Plasmid pML was constructed according to the general scheme outlined in Fig. 1. Plasmid pCH110
[16] was digested with HindIII and BamHI; then a $3.8-\mathrm{kb}$ fragment containing an E. coli lacZ gene was treated with T4 DNA polymerase and ligated to BamHI linker (Takara Co. Ltd.). After digestion with $\mathrm{BamHI}$, the lac $\mathrm{Z}$ fragment was inserted into the BglII site of the plasmid pMK [17].

\section{DNA preparation for microinjection}

Plasmid pML was digested with PstI, and the 5.7-kb fragment (designated $\mathrm{ML}$ ) containing the lacZ gene fused to mouse MT-I promoter was purified in a silica matrix (Geneclean, Bio 101 Inc.) after electrophoresis in a $0.8 \%$ agarose gel. ML was dissolved in $10 \mathrm{mM}$ Tris-0.1 mM EDTA solu-

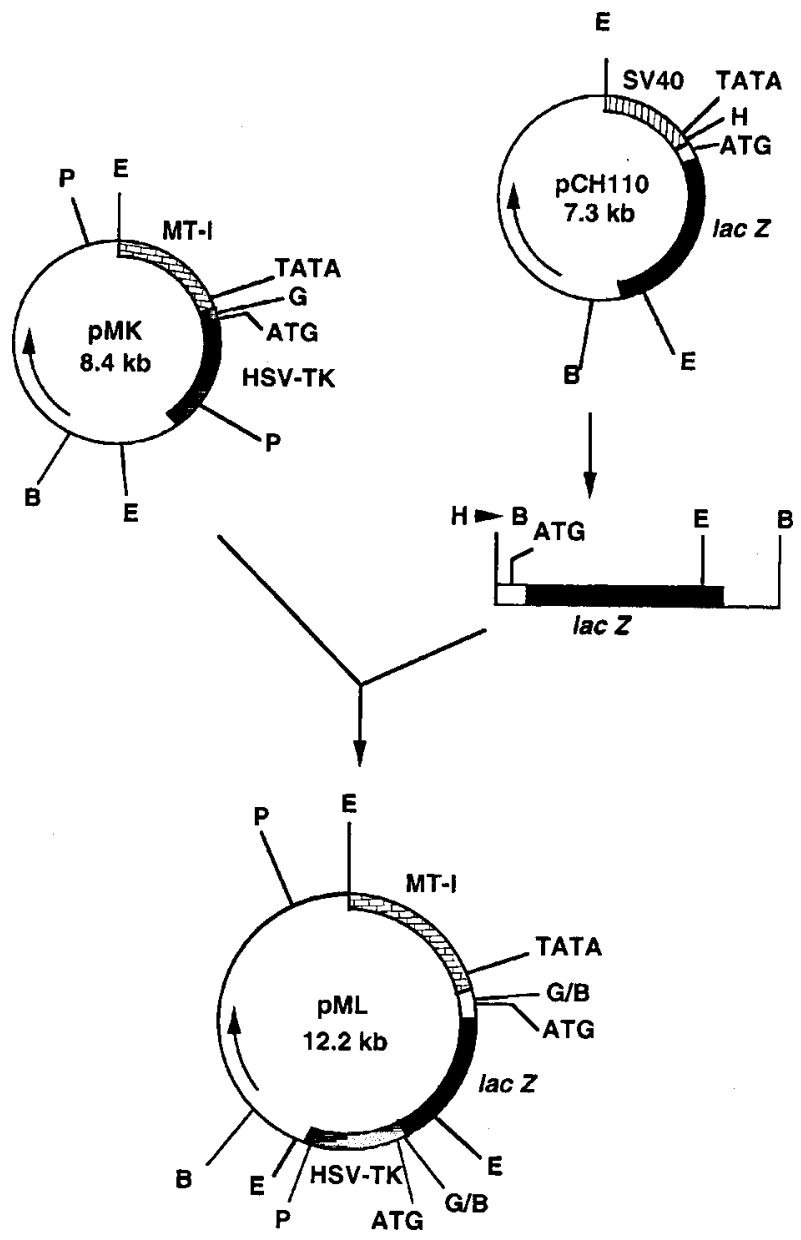

Fig. 1. Construction of plasmid pML. Arrow indicates an ampicillin-resistance gene. E, Eco RI; P, Pst I; B, Bam HI; G, Bgl II; H, Hind III; TATA, TATA box; ATG, translation initiation; SV40, SV40 promoter; MT-I, MT-I promoter; HSV-TK, herpes simplex virus thymidine kinase gene. 
tion ( $\mathrm{pH} 7.4$ ). At $8-10 \mathrm{hpi}$, the DNA solution at the concentrations of $0.05-50 \mathrm{ng} / \mu \mathrm{l}$ was microinjected into a pronucleus of each fertilized mouse egg.

\section{Detection of lacZ expression}

$X$-gal staining for detection of $\beta$-galactosidase activity was performed as described previously [11]. Briefly, embryos were rinsed with PBS (pH 7.2) and then fixed for $10 \mathrm{~min}$ at $4 \mathrm{C}$ with $0.25 \%$ glutaraldehyde in PBS. Embryos were washed in PBS and then incubated for $12 \mathrm{~h}$ at $37 \mathrm{C}$ in air, in a staining solution consisting of $0.04 \%$ 5-bromo-4chloro-3-indolyl- $\beta$-D-galactopyranoside (X-gal), 1 $\mathrm{mM} \mathrm{MgCl}, 10 \mathrm{mM}$ potassium ferricyanide, and 10 $\mathrm{mM}$ potassium ferrocyanide in PBS.

\section{Results}

\section{Development of injected embryos}

To evaluate the survival and subsequent development of the mouse embryos after DNA injection,
$0.05-50 \mathrm{ng} / \mu \mathrm{l}$ (approximately 10-10000 copies) of ML was microinjected into the pronuclei; subsequently, 66-95\% of zygotes cleaved into 2-cell embryos within 24 hpi (Table 1). Development of these embryos beyond the 2-cell stage in media containing EDTA is summarized in Table 2, which shows that there was no significant difference between 0.05 and $5 \mathrm{ng} / \mu \mathrm{l}$, although development was markedly inhibited after injection of $50 \mathrm{ng} / \mu \mathrm{l}$ of ML.

Frequency of embryos expressing lacZ in each developmental stage

When examined at $24 \mathrm{~h}$ intervals, $\beta$-galactosidase activity was initially detected at $48 \mathrm{hpi}$ in 4-cell embryos derived from eggs injected with ML at concentrations of $0.05-5 \mathrm{ng} / \mathrm{ml}$ (Fig. 2A). The frequency of embryos showing X-gal staining increased in a dose-dependent manner, reaching the highest level $(72 \%)$ in the embryos that had been injected with $5 \mathrm{ng} / \mu \mathrm{l}$ of ML. Injection of 50 $\mathrm{ng} / \mu \mathrm{l}$ resulted in an entirely different pattern of expression; staining was observed in $73.9 \%$ of $2-$

Table 1. Development to 2-cell stage of mouse embryos after the microinjection of ML gene

\begin{tabular}{ccc}
\hline \multirow{2}{*}{$\begin{array}{c}\text { Concentration of DNA } \\
(\mathrm{ng} / \mu \mathrm{l})\end{array}$} & \multicolumn{2}{c}{ Number of embryos } \\
\cline { 2 - 3 } & Survived $^{\mathrm{a}}$ & Development to 2-cell stage (\%) \\
\hline 0 & 86 & $74(98.6)^{\mathrm{a}}$ \\
0.05 & 255 & $242(94.9)^{\mathrm{a}}$ \\
0.5 & 304 & $281(92.4)^{\mathrm{a}}$ \\
5 & 304 & $199(65.5)^{\mathrm{b}}$ \\
50 & 111 & $81(73.0)^{\mathrm{b}}$ \\
\hline
\end{tabular}

aSurvival of the eggs was judged by morphology at $1 \mathrm{~h}$ after microinjection. Values with different superscript represent significant difference in the same column $(\mathrm{p}<0.05)$.

Table 2. Development of mouse embryos in vitro after the microinjection of ML gene

\begin{tabular}{crcc}
\hline $\begin{array}{c}\text { Concentration of DNA } \\
(\mathrm{ng} / \mu \mathrm{l})\end{array}$ & \multicolumn{3}{c}{ Percentage of embryos developed to } \\
\cline { 2 - 4 } & 4-cell (48 hpi) & Morula (72 hpi) & Blastocyst (96 hpi) \\
\hline 0 & $97.3^{\mathrm{a}}(73)$ & $94.6^{\mathrm{a}}(72)$ & $67.6^{\mathrm{a}}(50)$ \\
0.05 & $89.3^{\mathrm{b}}(56)$ & $66.7^{\mathrm{b}}(60)$ & $50.0^{\mathrm{b}}(54)$ \\
0.5 & $89.6^{\mathrm{b}}(67)$ & $59.4^{\mathrm{b}}(64)$ & $48.4^{\mathrm{b}}(62)$ \\
5 & $85.7^{\mathrm{b}}(35)$ & $68.6^{\mathrm{b}}(35)$ & $56.7^{\mathrm{b}}(30)$ \\
50 & $5.6^{\mathrm{c}}(36)$ & $8.3^{\mathrm{c}}(36)$ & $5.6^{\mathrm{c}}(34)$ \\
\hline
\end{tabular}

Values with different superscript represent significant difference in the same column $(p<0.05)$. Number of embryos examined is shown in paretheses. 

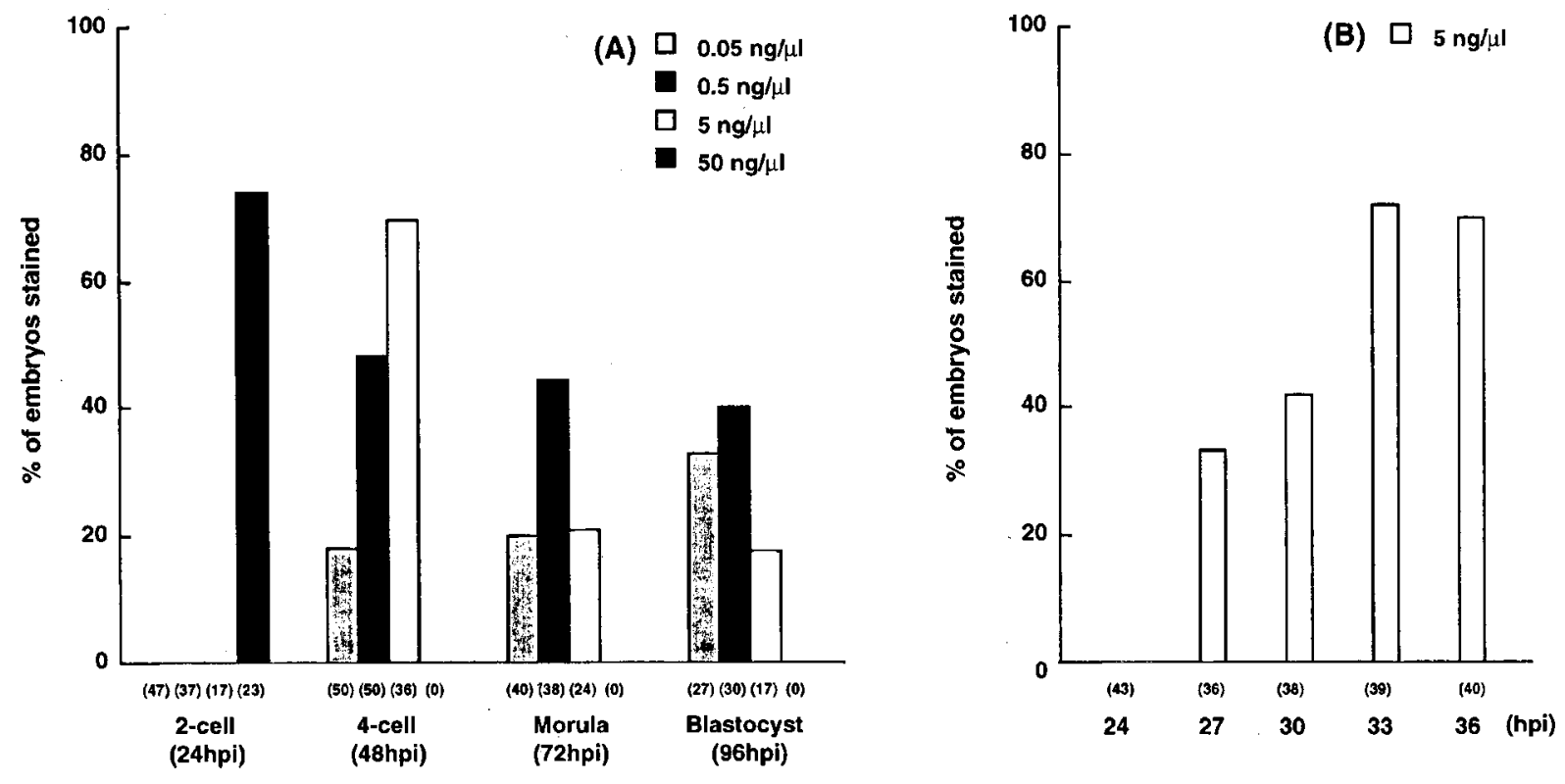

Fig. 2. (A) Staining frequency of embryos microinjected at the pronuclear stage with $0.5-50 \mathrm{ng} / \mu \mathrm{l} \mathrm{ML}$. Two-cell, 4cell, morula and blastocyst embryos were examined at 24, 48, 72 and $96 \mathrm{hpi}$, respectively. Embryos were cultured in Whitten's medium supplemented with EDTA. The number of embryos examined is shown in parentheses. (B) Staining frequency of 2-cell stage embryos 24-36 hpi after microinjection with ML (5 ng/ $\mu$ l) at the pronuclear stage (8-10 hpi). Embryos were cultured in Whitten's medium supplemented with EDTA. Number of embryos examined is shown in parentheses.

cell stage embryos as early as $24 \mathrm{hpi}$, although the intensity of the staining was weak. Staining could not be examined at later stages because after 24 hpi development of those embryos was strongly suppressed.

\section{Timing of ML expression}

To clarify when the exogenous $\beta$-galactosidase began to express, $\mathrm{X}$-gal staining was carried out at $3 \mathrm{~h}$ intervals from $24 \mathrm{hpi}$ to $36 \mathrm{hpi}$, using embryos that had been injected with $5 \mathrm{ng} / \mu \mathrm{l}$ of ML. All of the embryos examined were at the 2-cell stage during this period, and $\beta$-galactosidase activity was detected initially at 27 hpi in $33 \%$ of the embryos (Fig.2B). The frequency increased as the culture period lengthened.

To examine whether the $\beta$-galactosidase activity detected at $36 \mathrm{hpi}$ had originated from newly synthesized mRNA, its expression was examined in embryos cultured in the presence of $\alpha$-amanitin, an inhibitor of RNA polymerase II. $0.1-500 \mu \mathrm{g} / \mathrm{ml}$ of $\alpha$-amanitin was added to the culture medium containing EDTA at $12 \mathrm{hpi}$, and X-gal staining was carried out at $36 \mathrm{hpi}$. The addition of $\alpha$-amanitin suppressed the expression of the lac $Z$ gene in a dose-dependent manner, a significant inhibition being observed at $10 \mu \mathrm{g} / \mathrm{ml}$ or higher concentrations of $\alpha$-amanitin (Fig. 3A). At these concentrations, $\alpha$-amanitin also prevented the development of uninjected embryos to the 4-cell stage (Table 3). To further clarify the beginning of transcription, $10 \mu \mathrm{g} / \mathrm{ml}$ of $\alpha$-amanitin was added at different times between 12 and $24 \mathrm{hpi}$, and $\beta$-galactosidase activity was examined at $36 \mathrm{hpi}$ by $\mathrm{X}$-gal staining. The results presented in Fig. 3B show that the activity was detected in $35 \%$ of embryos that had been treated with $\alpha$-amanitin at $15 \mathrm{hpi}$, when all of the embryos were still at the 1-cell stage. The inhibitory effect of $\alpha$-amanitin on $\beta$ galactosidase activity was less under the treatment after the embryos had already developed to the 2cell stage.

\section{Effects of EDTA and $\mathrm{ZnCl}_{2}$ on induction of $\mathrm{ML}$ expression}

After pronuclear microinjection of ML, embryos were incubated in Whitten's medium with or without $100 \mu \mathrm{M}$ EDTA. Media were supplemented with $25 \mu \mathrm{M} \mathrm{ZnCl}_{2}$ at $24 \mathrm{~h}(12 \mathrm{~h}$ as for examination of 2cell stage embryos) before X-gal staining. The 
(A)
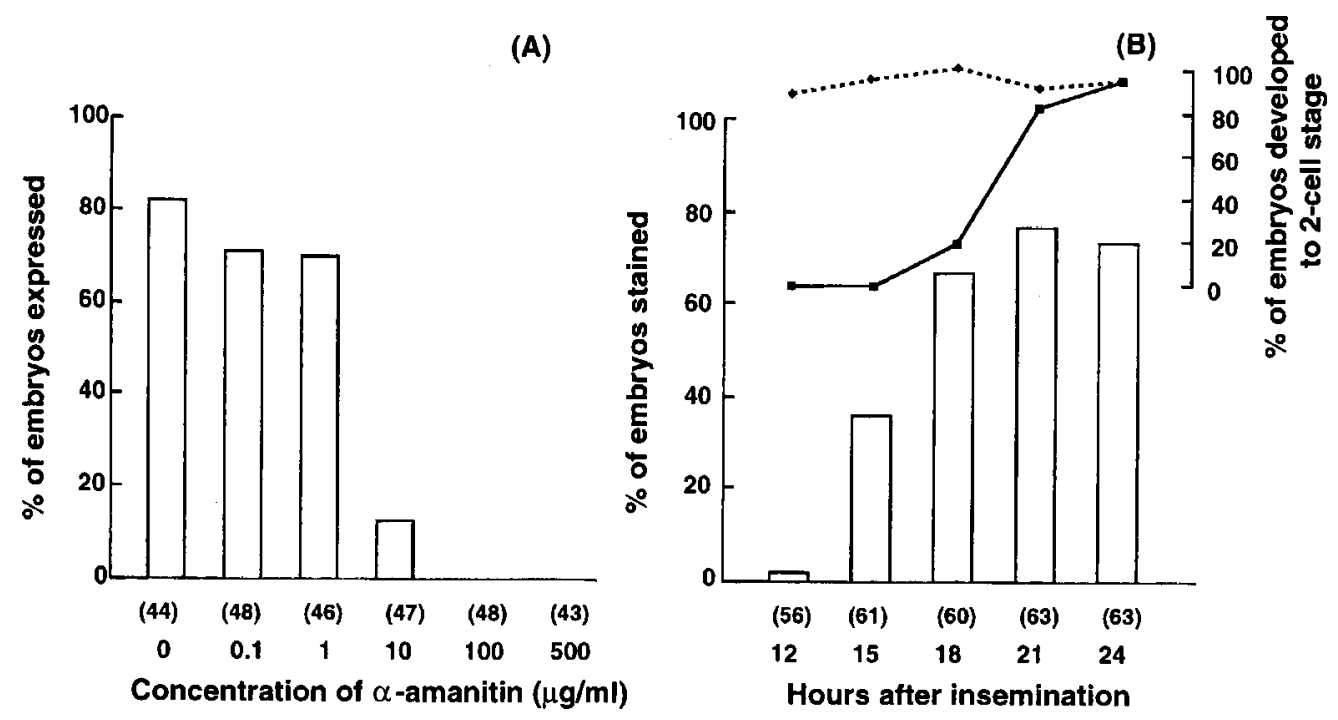

Fig. 3. (A) Inhibition of ML expression by $\alpha$-amanitin. $\alpha$-Amanitin $(0.1-100 \mu \mathrm{g} / \mathrm{ml})$ was added at 12 hpi to Whitten's medium containing EDTA, and X-gal staining was carried out at 36 hpi. Number of embryos examined is shown in parentheses. (B) Inhibition of ML gene expression with $10 \mu \mathrm{g} / \mathrm{ml}$ of $\alpha$-amanitin. Open bars indicate percentages of embryos stained. Number of embryos examined is shown in parentheses. Thick line indicates percentages of embryos developed to 2-cell stage when $\alpha$-amanitin was added to the culture medium. Dotted line tracks percentages of 2-cell embryos at the time of X-gal staining (36 hpi).

Table 3. Effect of $\alpha$-amanitin on preimplantation development

\begin{tabular}{cccccc}
\hline$\alpha$-amanitin & No. of eggs & \multicolumn{4}{c}{ Percentage of embryos developed to } \\
\cline { 3 - 6 }$(\mu \mathrm{g} / \mathrm{ml})$ & examined & 2-cell $(24 \mathrm{~h})$ & 4 -cell $(48 \mathrm{~h})$ & Morula $(72 \mathrm{~h})$ & Blastocyst $(96 \mathrm{~h})$ \\
\hline 0 & 32 & $100.0^{\mathrm{a}}$ & $84.4^{\mathrm{a}}$ & $93.8^{\mathrm{a}}$ & $87.5^{\mathrm{a}}$ \\
0.1 & 26 & $100.0^{\mathrm{a}}$ & $76.9^{\mathrm{a}}$ & $92.3^{\mathrm{a}}$ & $76.9^{\mathrm{a}}$ \\
1 & 27 & $100.0^{\mathrm{a}}$ & $40.7^{\mathrm{b}}$ & $18.5^{\mathrm{b}}$ & $0.0^{\mathrm{b}}$ \\
10 & 29 & $100.0^{\mathrm{a}}$ & $0.0^{\mathrm{c}}$ & $0.0^{\mathrm{c}}$ & $0.0^{\mathrm{b}}$ \\
100 & 27 & $100.0^{\mathrm{a}}$ & $0.0^{\mathrm{c}}$ & $0.0^{\mathrm{c}}$ & $0.0^{\mathrm{b}}$ \\
\hline
\end{tabular}

Values with different superscript represent significant difference in the same column $(\mathrm{p}<0.05)$. $\alpha$-Amanitin was added to the medium at $12 \mathrm{hpi}$.

results of the assays for $\beta$-galactosidase activity are shown in Fig. 4. In the presence of EDTA, much higher activity was observed at the morula and blastocyst stage when $\mathrm{ZnCl}_{2}$ was added to the culture medium (Fig. 4A). In the absence of EDTA, however, the activity was comparable in the embryos from 4-cell through blastocyst stage whether or not $\mathrm{ZnCl}_{2}$ was in the culture medium (Fig. 4B).

\section{Discussion}

Most of the embryos microinjected with $0.05-5$ $\mathrm{ng} / \mu \mathrm{l}$ of ML and cleaved to the 2-cell stage developed to the blastocyst stage by 96 hpi in Whitten's medium supplemented with $100 \mu \mathrm{M}$ of EDTA. On the other hand, the development to the 4-cell stage was markedly suppressed when the embryos were injected with a higher concentration $(50 \mathrm{ng} / \mu \mathrm{l})$ of ML. This result indicates that injection of too much DNA inhibits subsequent development of embryos. We therefore chose an ML concentration of 5 $\mathrm{ng} / \mathrm{ml}$ to examine transcriptional activity of the injected gene in preimplantation embryos. We consider this concentration, which is definitely lower than that used by other investigators [18-20], to approximate the actual physiological context of zygotic gene activation.

None of the 2-cell embryos expressed the exogenous gene product before $24 \mathrm{hpi}$ except for those 

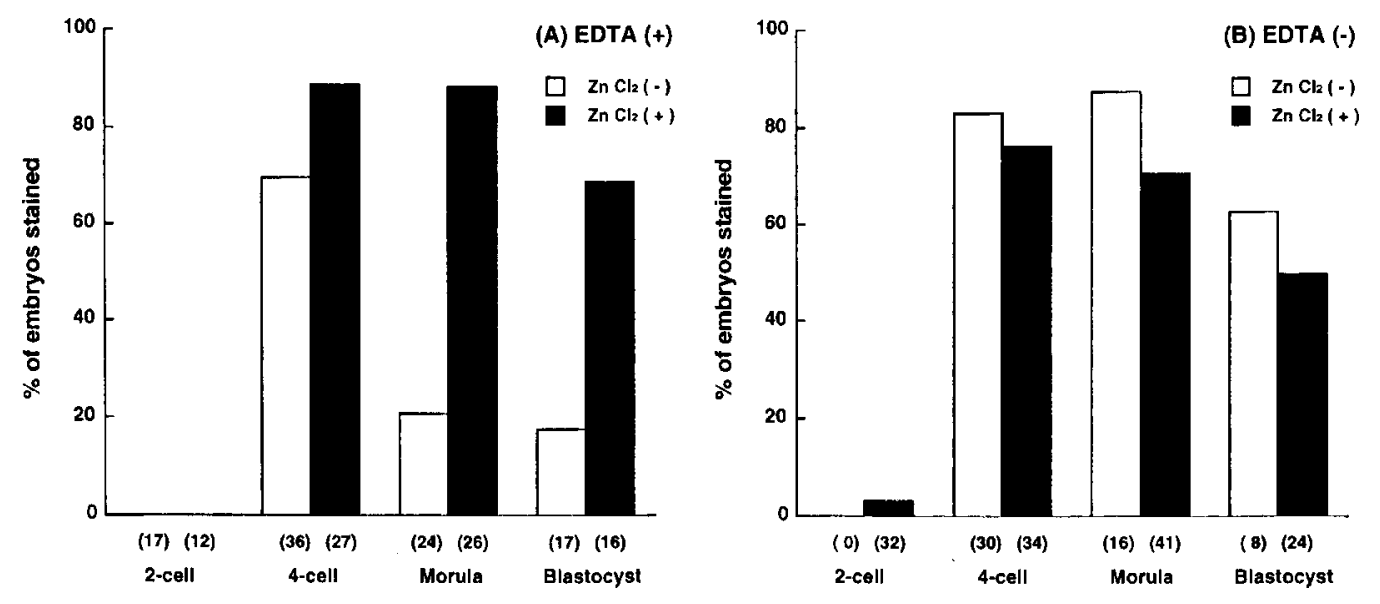

Fig. 4. Effects of supplementation with $25 \mu \mathrm{M} \mathrm{ZnCl}$ on expression of $\mathrm{ML}$ in preimplantation mouse embryos. Embryos were microinjected with ML $(5 \mathrm{ng} / \mu \mathrm{l})$ at the pronuclear stage and cultured in Whitten's medium with (A) or without (B) EDTA. Results from embryos cultured in medium with and without $\mathrm{ZnCl}_{2}$ are depicted as slanted and open bars, respectively.

injected with the higher concentrations of ML mentioned above. Initially, lacZ gene product was detected at 27 hpi by X-gal staining, and the frequency of positively stained embryos increased after that. After the 4-cell stage the frequencies decreased, but about one-fifth of the blastocysts still showed lacZ staining. Stevens et al. [21] examined expression of mouse MT-I-E. coli $\beta$-galactosidase fusion gene (plasmid pMT $\beta$ gal and its insert) in mouse preimplantation embryos after pronuclear microinjection at a concentration of 1.67 $\mathrm{ng} / \mu \mathrm{l}$. In their experiments lac $Z$ expression was detected in few or none of the embryos in the absence of heavy metal. In the present study, more than half of the embryos showed positive staining without $\mathrm{ZnCl}_{2}$ supplementation even in the presence of EDTA. To clarify the causes of this discrepancy, we tried using the same DNA solvent (10 mM Tris-1mM EDTA) used by them, but $66.7 \%$ of microinjected embryos at the 4-cell stage (48 hpi) still showed positive staining (data not shown). Therefore the difference between our results and those of Stevens et al. is probably not due to the composition of the DNA solvents employed. In their report, the length of the MT-I promoter is not clear, and their constructs can be expected to produce a fusion protein consisting of tufB, E. coli peptide elongation factor, and the lac $Z$ gene; our ML construct contains a 1.8-kb EcoRIPstI fragment and is designed to express a fusion protein consisting of tryptophanyl tRNA synthetase and lacZ [16]. Differences in the efficiency of transcription and/or translation of each construct, together with subtle changes in the structure of the fusion proteins produced, may provoke the discrepancy in these results. Differences in mouse strains and/or culture media could be also ascribed to the differences in the expression.

$\beta$-Galactosidase activity was detected initially at $27 \mathrm{hpi}$ in $33 \%$ of 2-cell embryos, and the frequency of detection increased thereafter. The addition of $\alpha$-amanitin at 12 hpi suppressed the expression of the injected gene in a dose-dependent manner, but complete inhibition did not appear if the embryos were treated with the drug only after $15 \mathrm{hpi}$. Flach et al. [22] reported that activation of the embryonic genome occurs both 18-21 hpi and 26-29 hpi, on the basis of the effect of $\alpha$-amanitin on patterns of protein synthesis. Recent studies suggest that transcription may be already initiated prior to the 2-cell stage in the mouse embryo. Ram and Schultz et al. [20] showed that SV40 early promoter-driven luciferase gene was expressed in G2 phase of 1-cell mouse embryos, and Wiekowski et al. [23] reported that the male pronucleus may foster a higher level of transcription than the female pronucleus. Bouniol et al. [24] reported endogenous transcription by RNA polymerase II takes place at late 1-cell stage ( $27 \mathrm{~h}$ after hCG, estimated at $15 \mathrm{hpi}$ ) using a fluorescent method allowing the detection of in vivo RNA synthesis. Our results suggest that ML was transcribed at same time mentioned above, and the 
transcription of ML may reflect that activation of embryonic genome occurs during the pronuclear stage.

The activity of $\beta$-galactosidase, however, became apparent in our experiments only at $27 \mathrm{hpi}$. The interval of $12 \mathrm{~h}$ between the estimated time of transcriptional initiation $(\sim 15 \mathrm{hpi})$ and the detection of gene product ( $27 \mathrm{hpi}$ ) may suggest that the ML transcript was under some control of translation, or it may reflect the time needed for accumulation of translated product in an amount sufficient for detection by the X-gal staining method. Vernet $e t$ al. [25] observed that lacZ RNA, but not lacZ DNA, microinjected during the first cleavage was expressed at 18-19 hpi and suggested that there may be a negative control for translation before 18-19 hpi. We detected the product of ML in nearly the same period as the endogenous genes expressed in early stage embryos reported by Andrews et al. [26].

EDTA exerted a slight but significant inhibition on expression of the ML gene. Inhibition was not obvious at the 4-cell stage, but became apparent at the morula stage, $72 \mathrm{hpi}$. This results implies that the expression of ML in late 2-cell and 4-cell stage embryos is independent of environmental factors, while the expression at later stages is not. Contaminating $\mathrm{Zn}^{2+}$ in our culture medium was estimated to be $\sim 0.6 \mu \mathrm{M}$ by atomic-absorption analysis (data not shown); addition of $25 \mu \mathrm{M}$ of $\mathrm{ZnCl}_{2}$, a concentration sufficient to induce the expression of genes from MT-I promoter [27, 28], did not suppress development of the embryos used in this study (data not shown). As EDTA did not reduce the expression in the presence of $25 \mu \mathrm{M} \mathrm{ZnCl}_{2}$, it is likely that EDTA suppressed the MT-I promoter by chelating the minute amount of contaminating $\mathrm{Zn}^{2+}$ or unidentified heavy metals.

Addition of $\mathrm{ZnCl}_{2}$ did not induce the expression of ML in 2-cell embryos before $24 \mathrm{hpi}$, but enhancement of expression was observed in 4-cell and later stages. Brinster et al. [27] showed that cadmium enhanced expression of HSV-tk driven by mouse MT-I promoter in late 2-cell embryos. Ao et al. [28] showed that expression of pMT-HPRT was induced by $50 \mathrm{mM}$ cadmium in late 2-cell embryos. Muller et al. [29] reported that expression of Hsp70 was induced by heat treatment in blastocysts but not in 1-cell embryos, and Bevilacqua et al. [30] showed that hsp68-lacZ gene became heart-inducible in late morulae. Andrews et al. [26] observed that expression of endogenous MT-I was induced by heavy metals ( $\mathrm{Zn}$ and $\mathrm{Cd}$ ) in 4-cell embryos, but not in the 2-cell stage. From these features, together with our present results, it is suggested that preimplantation mouse embryos develop the capacity to respond to environmental conditions after activation of the embryonic genome.

\section{Acknowledgement}

This study was supported in part by grant-inaid from the Ministry of Education, Science and culture of Japan.

\section{References}

1. Bachvarova $R$, De L, Johnson A, Kaplan G, Paynton BV. Changes in total RNA, polyadenylated RNA, and actin mRNA during meiotic maturation of mouse oocytes. Dev Biol 1985; 108: 325-331.

2. Paynton BV, Rempel R, Bachvarova R. Changes in state of adenylation and time course of degradation of maternal mRNAs during oocyte maturation and embryonic development in the mouse. Dev Biol 1988; 129: 304-314.

3. Piko L, Clegg KB. Quantitative changes in total RNA, total poly(A), and ribosomes in early mouse embryos. Dev Biol 1982; 89: 362-378.

4. Giebelhaus DH, Heukkila JJ, Schlutz GA. Changes in the quantity of histone and actin mes- senger RNA during the development of preimplantation mouse embryos. Dev Biol 1983; 98: 148-154.

5. Graves RA, Marzluff WF, Giebelhous DH, Schultz GA. Quantitative and qualitative changes in histone gene expression during early mouse embryo development. Proc Natl Acad Sci USA 1985; 82: 5685-5689.

6. Sawicki JA, Magnuson T, Epstein CJ. Evidence for expression of the paternal genome in the twocell mouse embryo. Nature 1981; 294: 450-451.

7. Bolton VN, Oades PJ, Johnson MH. The relationship between cleavage, DNA replication, and gene expression in the mouse 2-cell embryo. J Embryol Exp Morphol 1984; 79: 139-163. 
8. Howlett SK. A set of proteins showing cell cycle dependent modification in the early mouse embryo. Cell 1986; 45: 387-396.

9. Petzoldt U, Muggleton-Harris A. The effect of the nucleocytoplasmic ratio on protein synthesis and expression of a stage-specific antigen in early cleaving mouse embryos. Development 1987; 99: 481-491.

10. Schultz RM. Regulation of zygotic gene activation in the mouse. Bioassays 1993; 15: 531-538.

11. Takeda S, Toyoda Y. Expression of SV40-lacZ gene in mouse preimplantation embryos after pronuclear microinjection. Mol Reoprod Dev 1991; 30: 90-94.

12. Toyoda Y, Yokoyama M, Hoshi T. Studies on the fertilization of eggs in vitro. I. In vitro fertilization of eggs by fresh epididymal sperm. Jpn J Anim Reprod 1971; 16: 147-151.

13. Whitten WK. Nutrient requirements for the culture of preimplantation embryos in vitro. In: Raspa G (ed.), Intrinsic and Extrinsic Factors in Early Mammalian Development. Advances in the Bioscience, vol.6. New York: Pegamon Press; 1971: 29-139.

14. Abramzuk J, Solter D, Koprowski H. The beneficial effect of EDTA on development of mouse one-cell embryos in chemically defined medium. Dev Biol 1977; 61: 378-383.

15. Hoshi M, Toyoda Y. The effect of EDTA on development of mouse embryos derived from in vitro fertilization. Jpn J Anim Reprod 1985; 56: 931-937.

16. Hall CV, Jacob PE, Ringold GM, Lee F. Expression and regulation of Escherichia coli lacZ gene fusions in mammalian cells. J Mol Appl Genet 1983; 2: 101-109.

17. Brinster RL, Chen HY, Trumbauer M, Senear AW, Warren R, Palmiter RD. Somatic expression of herpes thymidine kinase in mice following injection of a fusion gene into eggs. Cell 1981; 27: 223-231.

18. Majumder S, Miranda M, DePamphilis ML. Analysis of gene expression in mouse preimplantation embryos demonstrates that the primary role of enhancers is to relieve repression of promoters. EMBO J 1993; 12: 1131-1140.

19. Wiekowski M, Miranda M, DePamphilis ML. Regulation of gene expression in preimplantation mouse embryos: effects of the zygotic clock and the first mitosis on promoter and enhancer activi- ties. Dev Biol 1991; 147: 403-414.

20. Ram PT, Schultz RM. Reporter gene expression in G2 of the 1-cell mouse embryos. Dev Biol 1993; 156: 552-556.

21. Stevens ME, Meneses JJ, Pedersen RA. Expression of a mouse metallothionein-Escherichia coli $\beta$-galactosidase fusion gene (MT- $\beta$ gal) in early mouse embryos. Exp Cell Res 1989; 183: 319-325.

22. Flach G, Johnson MH, Braude PR, Taylor RA, Bolton VN. The transition from maternal to embryonic control in the 2-cell mouse embryo. EMBO J 1982; 1: 681-686.

23. Wiekowski M, Miranda M, DePamphilis ML. Requirements for promoter activity in mouse oocytes and embryos distinguish paternal pronuclei from maternal and zygotic nuclei. Dev Biol 1993; 159: 366-378.

24 Bouniol C, Nguyen E, Debey P. Endogenous transcription occurs at the 1-cell stage in the mouse embryo. Exp Cell Res 1995; 218: 57-62.

25. Vernet $\mathbf{M}$, Bonnerot $\mathbf{C}$, Briand $\mathbf{P}$, Nicolas JF. Changes in permissiveness for the expression of microinjected DNA during the first cleavages of mouse embryos. Mech Dev 1992; 36: 129-139.

26. Andrews GK, Huet-Hudson YM, Paria BC, McMaster MT, De SK, Dey SK. Metallothionein gene expression and metal regulation during preimplantation mouse embryo development (MT mRNA during early development). Dev Biol 1991; 145: 13-27.

27. Brinster RL, Chen HY, Warren R, Sarthy A, Palmiter RD. Regulation of metallothionein-thymidine kinase fusion plasmids injected into mouse eggs. Nature 1982; 296: 39-42.

28. Ao A, Monk M, Lovell-Badge R, Melton DW. Expression of injected HPRT minigene DNA in mouse embryos and its inhibition by antisense DNA. Development 1988; 104: 465-471.

29. Muller WU, Li GC, Goldstein L. Heat does not induce synthesis of heat shock proteins or thermotolerance in the earliest stage of mouse embryo development. Int J Hyperthermia 1985; 1: 97-102.

30 Bevilacqua A, Kinnunen LH, Bevilacqua S, Mangia F. Stage-specific regulation of mouse Hsp68 gene promoter in preimplantation mouse embryos. Dev Biol 1995; 170: 467-478. 